\title{
Heloisa Pontes, intérprete e intérpretes
}

Bernardo Fonseca Machado ${ }^{1}$

PONTES, Heloisa. Intérpretes da Metrópole: História Social e relações de gênero no teatro e no campo intelectual, 1940-1968. São Paulo: EDUSP, 2011. 464 p.

A palavra "intérpretes" oferece a chave de entrada para investigar o livro de Heloisa Pontes: Intérpretes da Metrópole: História Social e relações de gênero no teatro e no campo intelectual, 1940-1968. "Intérpretes" são as atrizes do moderno teatro paulista e as críticas do campo intelectual do período. As primeiras representando, no corpo e na voz, as mudanças da metrópole, as seguintes, como tradutoras de uma São Paulo em mutação.

Intérprete é também Heloisa Pontes, cujo livro é resultado da tese de livre-docência defendida no Departamento de Antropologia da Unicamp em 2008. Nele estão reunidos, em um arranjo de comparações complexas, pesquisas e artigos escritos em diferentes momentos da carreira. Alinhados, esses artigos tomam forma de capítulos. Pensados em uma relação especular, isto é, os primeiros rebatendo os últimos, o texto oferece ao leitor a experiência de uma comparação densa entre as relações de gênero e as biografias coletivas.

Heloisa realiza um estudo comparativo entre mulheres oriundas do campo intelectual (a saber, Lúcia Miguel Pereira, Patrícia Galvão e Gilda de Mello e Souza) e atrizes da esfera teatral (Cacilda Becker, Maria Della Costa, Nydia Licia, Tônia Carrero, Fernanda Montenegro e Cleyde Yáconis). A comparação aprofunda-se para além das duas esferas e faz emergir um sistema cultural em formação na cidade de São Paulo dos anos 1940 a 1960. O objetivo geral do texto é realizar um estudo do processo de metropolização de São Paulo na cena teatral e na vida intelectual, acompanhando a trajetória de vida dessa geração de atrizes e intelectuais materializadas em uma cena cultural paulista em plena formação.

1 Mestrando do Departamento de Antropologia Social da USP.

E-mail: bfmx@uol.com.br

revista ieb $n_{54} 2012$ set./mar. p. I83-I86 
Os temas que perpassam o livro são diversos: a metrópole, a formação de suas intérpretes, a experiência social e as relações de gênero. Como bem destaca Antonio Arnoni Prado na apresentação do livro, o texto está disposto na forma de um ensaio no qual as diferentes temáticas se entrelaçam e lançam luzes entre si. Não é de estranhar que a própria pesquisadora, oriunda do cruzamento entre antropologia, história, sociologia e literatura, misture referências bibliográficas diversas e apresente um texto repleto de nuances.

O primeiro capítulo do livro é dedicado à comparação entre os membros da revista Clima e os participantes da revista nova-iorquina Partisan Review. Comparando as duas gerações - e as duas cidades, São Paulo e Nova York -, a autora evidencia as diferenças entre origem social, o lugar do ensaio como gênero de escrita em cada um dos contextos, o impacto e a influência dos exilados europeus e as relações gênero que estavam em jogo. Desse modo, Heloisa lança luz às duas metrópoles que sofriam mudanças significativas em suas estruturas sociais. A presença da universidade e a formação de uma mentalidade acadêmica é elemento constitutivo da geração dos membros da revista Clima. Nota-se também a onda de transformações sociais e urbanas que se desenvolveram em cada uma das cidades, gerando a possibilidade de espaços para o recrutamento de novos agentes sociais.

Em seguida, verticalizando o olhar para as intelectuais, Heloisa se debruça sobre as trajetórias de Lúcia Miguel Pereira, Patrícia Galvão e Gilda de Mello e Souza. Pensadas na relação com seus parceiros amorosos e de trabalho, a autora investiga quais escolhas essas mulheres puderam ou não realizar nesse contexto. $\mathrm{O}$ ambiente intelectual, majoritariamente masculino, gerava uma sensação de insegurança constante para as mulheres se inserirem nesse campo.

Neste ponto, o livro sofre uma inflexão: a primeira parte, dedicada à esfera intelectual, é colocada em contraste ao campo teatral, tal como um espelho. Deste modo, Heloisa evidencia os contrastes. No teatro as mulheres sentiam-se socialmente seguras para saltos maiores e ousados na São Paulo do período: condições sociais e institucionais permitiram isto. A segunda parte do livro é dedicada à imersão no ambiente de produção teatral de São Paulo.

O terceiro capítulo destaca a influência da figura de dois artistas franceses na cena teatral brasileira dos anos 1940 e 1950: Louis Jouvet e Henriette Morineau. Heloisa ambienta a produção teatral paulista pelo olhar que esses intérpretes lançaram de fora. É na comparação com as referências oriundas da Europa e do sistema teatral já rotinizado francês, que a autora constrói - pela negativa - o ambiente cultural em São Paulo.

I84 revista ieb $n_{54} 2012$ set./mar. p. I83-I86 
Uma vez realizado isso, o livro passa a acompanhar a construção da cena teatral pela geração de mulheres, algo inédito nos livros de história do teatro. É na chave de uma geração de mulheres e de seus parceiros que o texto lança luz ao surgimento do moderno teatro brasileiro.

Artífices capitais desse momento, Décio de Almeida Prado e Cacilda Becker são analisados mais detidamente. A trajetória dos dois é pensada em alinhamento com as novas convenções estéticas que se estavam consolidando no teatro moderno proveniente da Europa - a primazia do texto, a presença do encenador, o trabalho do ator, entre outras. A autora apresenta, aos poucos, a geração de intelectuais e artistas ligados à renovação teatral: interpretando-a e fazendo parte dela. Como destaca o próprio Décio, artífice e intérprete do momento, houve uma sintonia de condições institucionais e de convenções estéticas que produziram a guinada para o moderno teatro brasileiro surgir.

A escolha dos nomes artísticos é o mote para o próximo capítulo, no qual Heloisa apresenta resumidamente a trajetória individual das atrizes do período. Segundo ela, no processo de construção social do artista e da pessoa combinam-se marcadores de gênero, classe e geração. Em seu argumento, os nomes artísticos escolhidos pelas atrizes derivam das relações de gênero e da própria trajetória de vida de cada uma.

O último capítulo analisa a relação entre as atrizes e seus parceiros amorosos e de trabalho. O renome conquistado por elas é inseparável dessas parcerias. Nesse trecho do livro é perceptível o salto analítico dado por Heloisa, que evidencia como a renovação teatral do período esteve entrelaçada não só às convenções estéticas, mas também às relações de gênero e às instituições que surgiram em São Paulo. É neste capítulo que a ótica especular do livro se configura, pois dialoga com a primeira parte, evidenciando a diferença da presença das mulheres no campo intelectual e teatral. As convenções e instituições de cada esfera oferecem possibilidades e limites diferentes para elas. Não se trata de dizer que as mulheres escolhiam livremente suas trajetórias, pelo contrário, suas estratégias e decisões estavam sempre acertadas com o contexto e com os eixos estruturais que as atravessaram. Se as intelectuais sofriam de uma insegurança em um ambiente masculino, as atrizes "mandavam no teatro".

A conclusão evidencia a presença de um sistema cultural denso e diversificado que se organizou na época. Heloisa aponta como houve convergência entre o teatro, a universidade e a cidade. Sincronicamente estes elementos se alinharam de tal forma que contribuíram para a conformação de um sistema cultural. 
Importante destacar também a natureza e propriedade das fontes utilizadas. Lançando mão de grande conjunto de material, Heloisa costura o texto com diversas referências: desde livros editados pelas intelectuais até entrevistas concedidas pelas atrizes em revistas semanais. Depoimentos, fotos, prêmios, críticas as mais diversas servem de material para interpretações e aprofundamento vertical nas trajetórias individuais. Partindo desse conjunto de dados, a autora consegue traçar as tão ricas comparações.

Comparar, por sinal, é o verbo que permeia todo o texto. A autora compara as intelectuais brasileiras com as intelectuais nova-iorquinas; analisa a relação das parcerias das intelectuais brasileiras com seus parceiros de trabalho; em seguida, desenvolve o argumento comparando as parcerias das intelectuais com as parcerias das atrizes; reflete sobre as diferentes variáveis das parcerias das atrizes, e assim por diante.

Ao final da leitura pode-se constatar que Heloisa fez uma escolha adequada dos objetos de pesquisa e do período analisado. O elenco de nomes escolhidos nas duas esferas de produção cultural foi fundamental no processo de renovação dos padrões de criação em cada campo. Os intérpretes de Clima foram responsáveis pela construção de interpretações sobre a história da cultura brasileira que ganharam fôlego e duração. As intérpretes teatrais alteraram não só a cena paulistana e brasileira como também as convenções estéticas e práticas teatrais, estabelecendo um marco definidor para a história do teatro. Além disso, o recorte temporal permite captar o período de transição significativa dos padrões sociais na cidade de São Paulo.

Entre intérpretes e interpretações, Heloisa trabalha tecendo um texto que elucida a conexão entre convenções estéticas e experiência social. Sob o eixo do gênero, as duas noções assumem uma dimensão nova que oferece um olhar preciso para pensar a formação do sistema cultural paulistano do período. Essas intérpretes da metrópole - oriundas do campo intelectual e da esfera teatral - traçaram seus destinos misturados à cidade, às parcerias amorosas e ao próprio trabalho. Traduziram uma nova versão de São Paulo, marcando sua geração e as posteriores. 